\title{
Climatology of Air Temperature in Belterra: Thermal Regulation Ecosystem Services Provided by the Tapajós National Forest in the Amazon
}

\author{
Lucieta Guerreiro Martorano $^{1}$ (D), Wanny Barbosa Soares ${ }^{2}$ (D), \\ José Reinaldo da Silva Cabral de Moraes $^{3}$ (D), Werlleson Nascimento ${ }^{4}$ (D), \\ Lucas Eduardo de Oliveira Aparecido ${ }^{5}$ (D), Pedro Manuel Villa ${ }^{6}$ \\ ${ }^{1}$ Embrapa Amazônia Oriental/NAPT do Médio Amazonas, Santarém, PA, Brasil. \\ ${ }^{2}$ Centro Universitário Luterano de Santarém CEULS/ULBRA, Santarém, PA, Brasil. \\ ${ }^{3}$ Universidade Estadual Paulista, Faculdade de Ciências Agrárias e Veterinárias, Departamento \\ de Ciências Exatas, Jaboticabal, SP, Brasil. \\ ${ }^{4}$ Universidade de São Paulo, Escola Superior de Agricultura "Luiz de Queiroz”, Departamento \\ de Ciências Exatas, Piracicaba, SP, Brasil. \\ ${ }^{5}$ Instituto Federal do Sul de Minas Gerais, Campus Muzambinho, MG, Brasil. \\ ${ }^{6}$ Universidade Federal de Viçosa, Departamento de Biologia, MG, Brasil.
}

Received: 22 May 2020 - Accepted: 13 January 2021

\begin{abstract}
The Tapajós National Forest (Flona Tapajós) has been providing important ecosystem services to society since the creation of this Conservation Unit in the Amazon. This study analyzed two climatic series from Belterra to identify possible effects on the thermal regime in the municipality as a function of the proximity of the Flona Tapajós and the consolidated grain production center in western Pará. Two climatological normal datasets from the National Institute of Meteorology (INMET) were analyzed (1961-1990 and 1981-2010). Analysis of variance was used to compare averages, extremes (minimums and maximums), and thermal amplitudes. Average temperature was $24.6{ }^{\circ} \mathrm{C}$ in the first semester (1961-1990) and $25.2{ }^{\circ} \mathrm{C}$ (1981-2010), with maximums of $29.4{ }^{\circ} \mathrm{C}$ and $29.9{ }^{\circ} \mathrm{C}$, and minimums of 20.6 and $21.2^{\circ} \mathrm{C}$, respectively. There were no statistical differences in these comparisons. In the second semester the averages increased to $25.2{ }^{\circ} \mathrm{C}$ and $26.0{ }^{\circ} \mathrm{C}$, and were statistically different, with maximums of $31.2{ }^{\circ} \mathrm{C}$ and $31.6{ }^{\circ} \mathrm{C}$ and minimums of $20.4^{\circ} \mathrm{C}$ and $21.2^{\circ} \mathrm{C}$, indicating different thermal regimes during 1981-2010. Additionally, from October to December the nights were warmer. The Flona Tapajós may have experienced a reduction in provision of ecosystem services, and the increase in minimum temperatures could be associated with grain production activities in the region.
\end{abstract}

Keywords: climatic events, West of Pará, climatic series, air temperature, thermal variations.

\section{Climatologia da Temperatura do Ar em Belterra: Serviço Ecossistêmico de Regulação Térmica Prestado Pela Flona Nacional do Tapajós na Amazônia}

\begin{abstract}
Resumo
A Floresta Nacional do Tapajós vem prestando importante serviço ecossistêmico à sociedade desde a criação dessa Unidade de Conservação na Amazônia. O objetivo neste trabalho foi avaliar o perfil climático de temperatura do ar em Belterra apontando evidência de serviço ecossistêmico de regulação térmica prestado pela Flona Tapajós na Amazônia. Duas normais climatológicas disponibilizadas pelo Instituto Nacional de Meteorologia (INMET) foram utilizadas (1961 a 1990 e 1981 a 2010). Na primeira série história a Flona Tapajós já existia e na segunda consolida-se o polo de grãos no município. Fez-se análise de variância no programa R para comparar médias, extremas (máximas e mínimas) e amplitudes térmicas. Verificou-se semelhança estatística no primeiro semestre nas duas séries temporais com médias de $24,6{ }^{\circ} \mathrm{C}$ e $25,2{ }^{\circ} \mathrm{C}$, máximas de $29,4{ }^{\circ} \mathrm{C}$ e $29,9{ }^{\circ} \mathrm{C}$ e, mínimas de 20,6 e $21,2{ }^{\circ} \mathrm{C}$, respectivamente. No segundo semestre, as médias passaram de $25,2{ }^{\circ} \mathrm{C}$ para $26,0{ }^{\circ} \mathrm{C}$, as máximas de $31,2{ }^{\circ} \mathrm{C}$ para $31,6{ }^{\circ} \mathrm{C}$ e as mínimas de $20,4{ }^{\circ} \mathrm{C}$ para $21,2{ }^{\circ} \mathrm{C}$
\end{abstract}

Autor de correspondência: Lucas Eduardo de Oliveira Aparecido, lucas.aparecido@muz.ifsuldeminas.edu.br. 
com significância estatística em aumento térmico entre 1981 a 2010. Entre outubro a dezembro as madrugadas ficaram mais quentes, evidenciando reduções de serviço ecossistêmico em regulação térmica prestado pela Flona Tapajós que pode estar associado à consolidação do polo de grãos em Belterra.

Palavras-chave: eventos climáticos, Oeste do Pará, séries climáticas, temperatura do ar, variações térmicas.

\section{Introduction}

Public policies that are implemented to organize agricultural production processes in the Brazilian Amazon must take into consideration biophysical and climatic variables, principally those that are related to thermal and hydrological conditions in the region (Marengo and Espinoza, 2015). Deforestation affects evapotranspiration processes through reductions in rainfall and increases in temperature (Sampaio et al., 2007), because soils without vegetation cover influence the dynamics of interactions with the atmosphere (Coe et al., 2009). Climatology describes the average state of the atmosphere, and in the Amazon high temperatures and rainfall are mediated by processes ranging from the direct effects of solar radiation and heat attenuation by cloud cover, to factors that are influenced by different scales of space and time (Marengo; Nobre, 2009, Reboita et al., 2010, Marengo and Espinoza, 2015).

Analyses of historical series can show possible effects such as seasonality and oscillations, and even indicate positive tendencies in average temperature and rainfall in the North region of Brazil (Salviano et al., 2016). Climate normals are used as a reference in such analyses since they indicate the average pattern of the atmosphere of a region during the previous 30 years of data, and can aid in the development of climate indicators such as the thermal spiral (Morice et al., 2012).

The thermal regime affects the rainfall regime in the Amazon. Moraes et al. (2020) related that the rainy season begins during the monthly quarter from December to February (DJF) in the Amazon. This quarter is modulated by the Intertropical Convergence Zone (ITCZ) and is associated with the effects of the South Atlantic Convergence Zone (SACZ) and the Bolivian High (Jahfer et al., 2020). The ITCZ acts to maintain or reduce the large belt of humidity in the region (Loureiro et al., 2014, Drumond et al., 2014), and beginning in the month of August there is a reduction in rainfall, including in areas that are prone to water stress (Martorano et al., 2017), indicating a reduction in soil water stocks.

In the western region of the state of Pará, in places such as Santarém and its vicinity, the dynamics of humidity are influenced by the Tapajós River, which forms a " $T$ " with the Amazon River and creates a low-level line of convergence (LLC) near the eastern margin of the Tapajós River which maintains the dominance of mechanical forcing factors as opposed to thermal ones (Lu et al., 2005).

In this region, technical and social economic capital investments could be more efficient and effective if they were planned based on climate patterns, anomalies, and agrometeorological models in order to aid in decisionmaking (Nobre et al., 2016; Villa et al., 2018a), principally in areas with substantial agricultural cultivation (Pattanayak et al., 2009; Villa et al., 2017), as well as in areas used for conservation (IPEA 2011; Nepstad et al., 2014). The climate is an important regional-scale abiotic factor that influences species diversity, and tree height and total biomass in the Amazon (Poorter et al., 2015).

It is important to emphasize that the environmental barriers imposed by the globalized market require the creation of indicators of sustainable development (Nepstad et al., 2014; Gibbs et al., 2015), including technical and social reforms with respect to the use of natural capital (Salahodjaev, 2016). Furthermore, decision-making with respect to public policies must also consider the concepts outlined in the Declaration on Forests, Agenda 21, and Agenda 2030, among other agendas focused on Sustainable Development Objectives (SDO) to which Brazil is a signatory. Soil management alternatives (Almeida et al.,) wherein production must be responsibly conducted to reduce hunger (SDO 2) without affecting the climate (SDO 13) are goals of the United Nations Organization.

However, there is still epistemological confusion over the concepts of preservation and conservation. Preservation can be defined as maintaining intact areas that are sensitive to a range of disturbances, such as ecological sanctuaries, tops of hills, natural springs, and areas that have a high risk of soil erosion, landslides, and floods (IBAMA, 2011). Conservation refers to rational and adequate use of a natural resource based on indicators of sustainability, including the potential for valuation through payment for ecosystem services (IPEA, 2011). The new Brazilian Forest Code reinforces the importance of areas of permanent preservation (APPs) which require special care.

Special attention should be given when in a specific municipality, such as Belterra, western Pará, there is an important Sustainable Use Conservation Unit (UCS), which in this case is the Tapajós National Forest (Flona Tapajós). Conservationist use of the Flona Tapajós and its surroundings should serve as a reference in analyses of anthropogenic effects on the climate regime (IPCC, 2013).

Negative environmental impacts such as fires, illegal deforestation, use of water resources without official granting of concession rights, and soil management practices that disperse soil particles into the atmosphere during hot and dry parts of the day or year are indicators that can intensify local thermal regimes (Fearside, 2001). Thermal forcing factors predominate in continental areas, with air 
temperature being an important variable for climate analyses (Sutton et al. 2018). Studies by Marengo and Espinoza (2016), showed tendencies for an increase in air temperature in the Amazon region, reinforcing that it is a sensitive variable for use in evaluation of the role of forests and their biodiversity in the mitigation of global climate change.

Tropical forests contribute to the maintenance of the global carbon cycle and to other goods and ecosystem services (Poorter et al., 2015), provide direct and indirect benefits such as oxygen and water production, among other benefits that are only vaguely perceived by society (Pizer et al., 2014)).

In this context, the objective of this study was to evaluate the climatic profile of air temperature in Belterra, with the ultimate goal of demonstrating that the Flona Tapajós provides important thermal regulation ecosystem services to this region of the Amazon.

\section{Materials and Methods}

Since Belterra integrates municipalities that compose the center of grain cultivation of western Pará, the thermal analyses conducted in this study aim to provide a basis for decision-making strategies. Data were taken from a conventional meteorological station (Latitude: $02^{\circ}$ 38'11" S, Longitude: 54 56'14" W and Altitude: $152 \mathrm{~m}$ ), collected by the National Institute of Meteorology (INMET) at this station which has been in operation for over 50 years in this region.

The municipality of Belterra is composed of areas that are used for agricultural cultivation and areas that provide important ecosystem services to the region, such as the Tapajós National Forest (Flona Tapajós). This Sustainable Use Conservation Unit (UCS), was created by decree in 1974 by the National Integration Program - PIN, and only in 1994 was the presence of communities in the FLONA officially permitted. The FLONA has an eastern border along the Santarém-Cuiabá highway and has great potential for tourism (Bacha e Rodriguez, 2007).

Santarém is a port city with a large commercial flux, principally due to grain export, the route for which occurs on local highways and waterways (Tapajós and Amazon Rivers). Soybeans are one of the principal products of the grain production chain, and planting predominantly occurs in mid-December, a period locally referred to as the first, or primary crop. In the second semester, with a reduction of rainfall in the region (Martorano et al., 2017), after soybean harvest these areas are prepared for a second crop cycle.

The hot and humid climate in the region is composed of two distinct periods, the rainy season from January to June, and the dry season from July to December (Martorano et al., 2017). During the period with lower rainfall anthropogenic actions are usually more intense, principally with respect to soil management for annual crops.

Climate type is $\mathrm{Am}_{3}$ in the southern, eastern, and western part of Belterra, and $\mathrm{Am}_{4}$ in the northern portion (Fig. 1), as defined by the Köppen climate classification system, adapted by Martorano et al. (1993) and described in Martorano et al. (2017), showing distinct climate patterns for monthly and annual rainfall, but with the same thermal regime.

Data from two separate climate normal were used, corresponding to the averages of homogeneous thermal series from 30 years of meteorological data. The first normal is from 1961 to 1990 , and the second is from 1981 to 2010. The analyzed data consisted of average, maximum, and minimum air temperature $\left({ }^{\circ} \mathrm{C}\right)$ for Belterra, made available by the National Institute of Meteorology (INMET). Thermal amplitudes and dispersion measures were used to compare the series for the first and second semesters and the quarterly periods from each normal.

A system of symbols was setup that represents the months of the year using the first letter from each month. In this way, in the first semester the data refer to the months from January to June, and in the second from July to December. It is important to emphasize that during the first semester most agriculture areas in this grain production center are planted with soybeans as the first crop harvested in the agricultural year, and in the second semester, after soybean harvest, soils are prepared for a second crop and agricultural year. Additionally, thermal amplitudes were used to identify if there were similarities or differences between the maximum and minimum values from the two historical series.

The software R (R CORE TEAM, 2019) was used for statistical analysis using Analysis of Variance (ANOVA) to test for differences between the two historical series, considering the thermal values of the two climatological normals. The semesters $\left(\mathrm{S}_{1}=\right.$ January to June and $\mathrm{S}_{2}=$ July to December) were separated. Additionally, months were grouped into quarters, indicated by capital letters and corresponding to the months of the year (JFM, AMJ, JAS, OND). The Tukey multiple comparison test was used at a significance level of $5 \%$ to separate means. Data from the climatological normals from the periods 1961 to 1990 and 1981 to 2010 for Belterra were used in the ANOVA. Therefore, the average conditions of climate patterns in Belterra over a 30-year period were used in this analysis, but due to overlap of some years between the two normal the total number of years included in this analysis was 50 (1961 to 2010).

The Flona Tapajós was created by decree in 1974, therefore the first climatological normal was used to formulate the questions used to direct the current analysis. Considering provision, support, regulation, and cultural ecosystem services, would it be possible to identify thermal differences that could demonstrate a reduction in eco- 


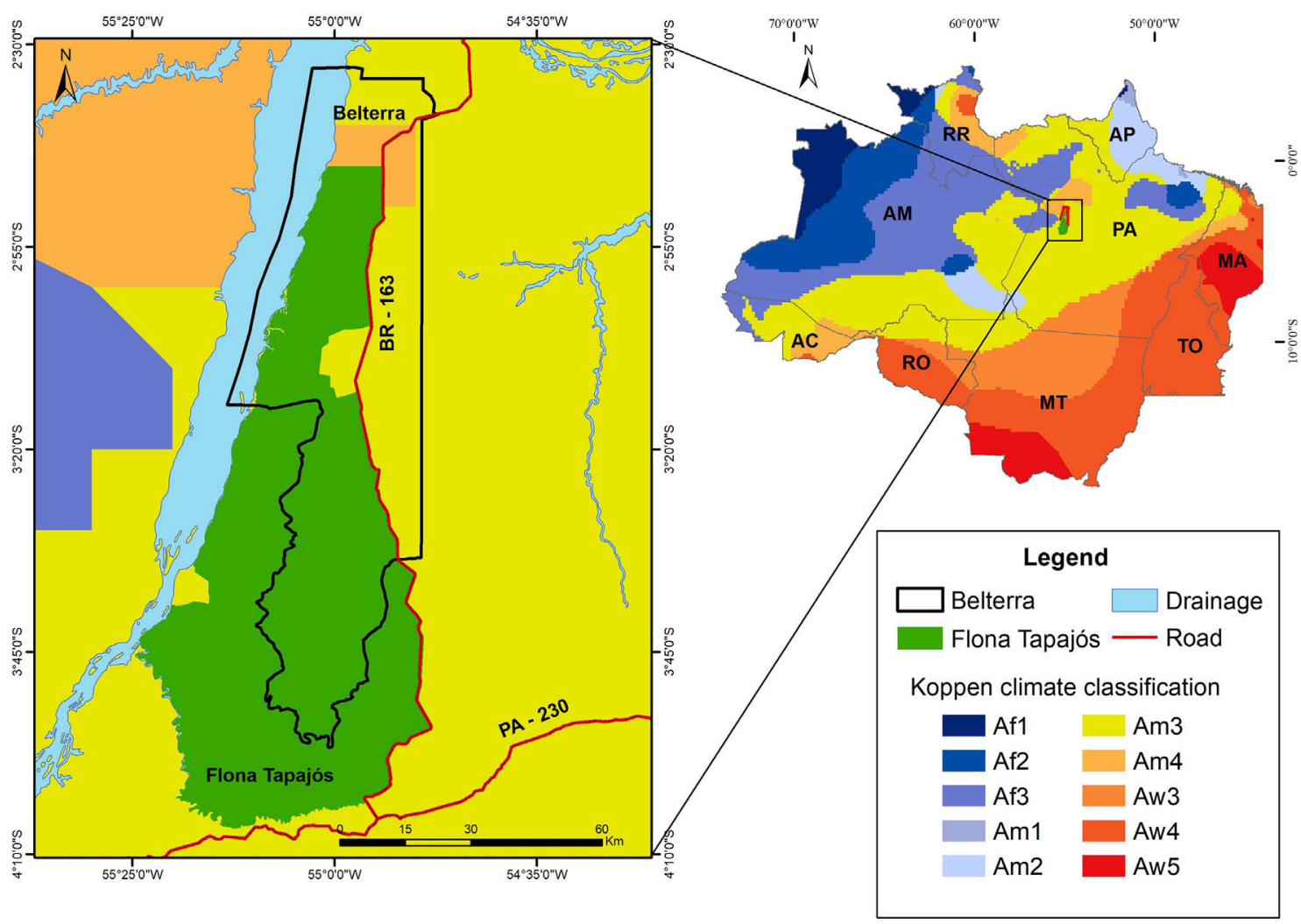

Figure 1 - Climatic typology of the Brazilian Amazon highlighting the municipality of Belterra, Pará.

system services such as thermal regulation provided by the Flona Tapajós since the implantation of the grain production center in western Pará starting in the year 2000?

Furthermore, can thermal regulation, as interpreted using a database of climatological normals, be used to aid in decision-making with respect to the adoption of conservationist actions? Would these actions have sufficient potential to be sanctioned and recognized by the National Climate Policy, which includes programs such as Payment for Environmental Service (PES) (Pagiola et al., 2013) thus increasing economic gains by rural producers and promoting positive environmental results?

If this analysis shows significant differences during the time interval analyzed then climate normals can be considered to be climatic variables that can serve as a base to convince new stakeholders to adopt sustainable production systems to promote sustainable production in the grain production center in western Pará.

\section{Results and Discussion}

Air temperatures were higher during the last climate series from 1981 to 2010, both at monthly (Fig. 2.a) and semester timescales (Fig. 2.b). During the first climatological thermal profile from January to June average temperatures in Belterra varied between $24.6{ }^{\circ} \mathrm{C}$ to $25.2{ }^{\circ} \mathrm{C}$, with maximum values between $29.4{ }^{\circ} \mathrm{C}$ and $31.2{ }^{\circ} \mathrm{C}$ and minimums between $20.4{ }^{\circ} \mathrm{C}$ and $20.6{ }^{\circ} \mathrm{C}$ (Fig. 2.a). During the second climatological normal average temperatures in Belterra were $25.2{ }^{\circ} \mathrm{C}$ in the first semester and $26.0^{\circ} \mathrm{C}$ in the second semester, with maximums of $29.9{ }^{\circ} \mathrm{C}$ and $31.6{ }^{\circ} \mathrm{C}$ and equal values for the minimum of $21.2{ }^{\circ} \mathrm{C}$, respectively.

Minimum temperatures showed reduced variation, but thermal differences occurred when semester timescales were analyzed. The dispersion in the values in the second semester showed that thermal conditions were more erratic, as demonstrated by the distances between the quartiles in the boxplots (Fig. 2.b) which show the corresponding values of the climatological normals. This thermal variability in the second semester is a strong indicator of a reduction in the precision of models during this period of the year when considering that air temperature is a dependent variable with respect to other variables in the soil-plant-atmosphere system.

The boxplots that represent the series from 1961 to 1990 show that maximum values were below the values from the second climatological normal (Fig. 2.a), and this is reinforced by the centroid which indicates higher averages in the series from 1981 to 2010. Another important aspect that should be emphasized in this comparison of the two climatological series is that the early mornings before sunrise in Belterra were hotter, and this is explained by the increase in minimum temperatures in the municipality. 


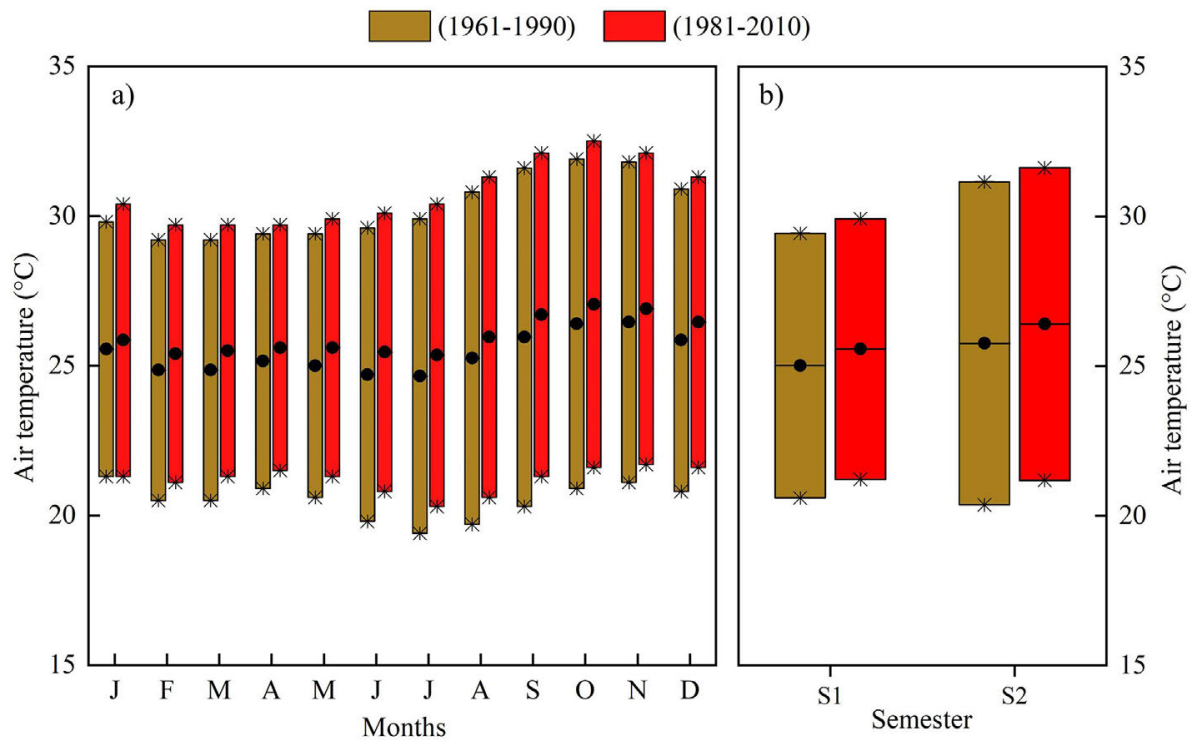

Figure 2 - Thermal climate profile based on two climatological normals (1961 to 1990 and 1981 to 2010) on a monthly scale from January to December (a) and semester timescale considering S1 the first semester and S2 the second semester (b) in Belterra, Pará.

Thermal amplitude was $11.3{ }^{\circ} \mathrm{C}$ greater in September during the second semester for the first climatological normal (Fig. 3). In the second semester in October the amplitude was $10.9^{\circ} \mathrm{C}$. From January to April in both periods thermal amplitudes were reduced (Fig. 3 and 4), demonstrating that during this part of the year temperatures are attenuated by the presence of large- and mesoscale systems that modulate rainfall in the region.

The analysis of the entire 50-year period from 1961 to 2010 showed that semester minimums were not different, but that temperature increases were detected during the quarter from October to December, indicating warmer early morning periods before sunrise in the period 1981 to

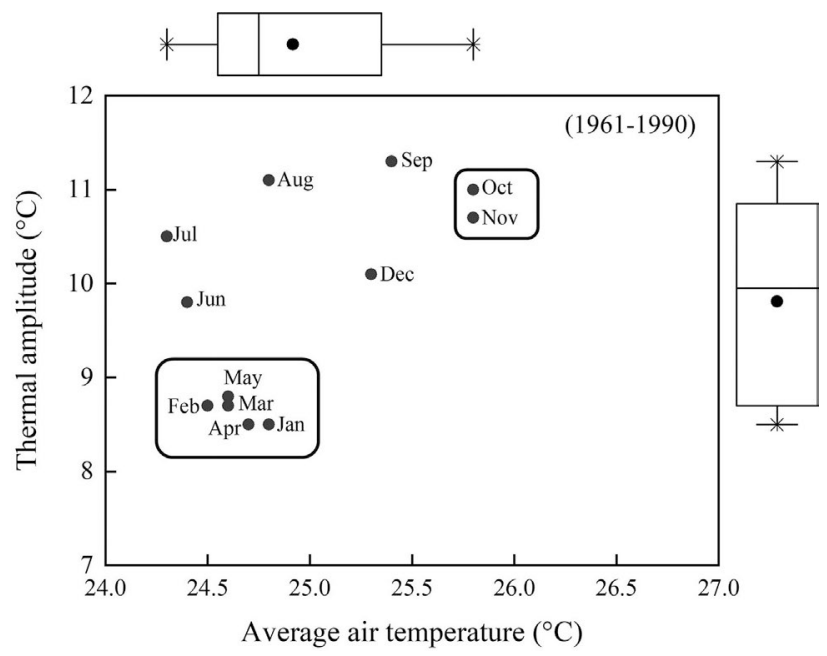

Figure 3 - Thermal climate profile of the thermal amplitude of air temperature and average air temperature from January to December during the period 1961 to 1990 in Belterra, Pará.
2010, as compared to the values from 1961 to 1990 . If minimum temperatures were higher during the second climatological normal, this suggests local effects during this quarter that are maintained over the course of many years, promoting alterations that can be detected when comparing means of minimum temperatures from October to December.

At a semester timescale average air temperature was similar during the first semester for each climatological normal with no statistically significant differences (Table 1). The low variability in the temperature values, when analyzed on a semester basis, is shown by the coefficient of variation $(\mathrm{CV})$ of $1.8 \%$ of the average tempera-

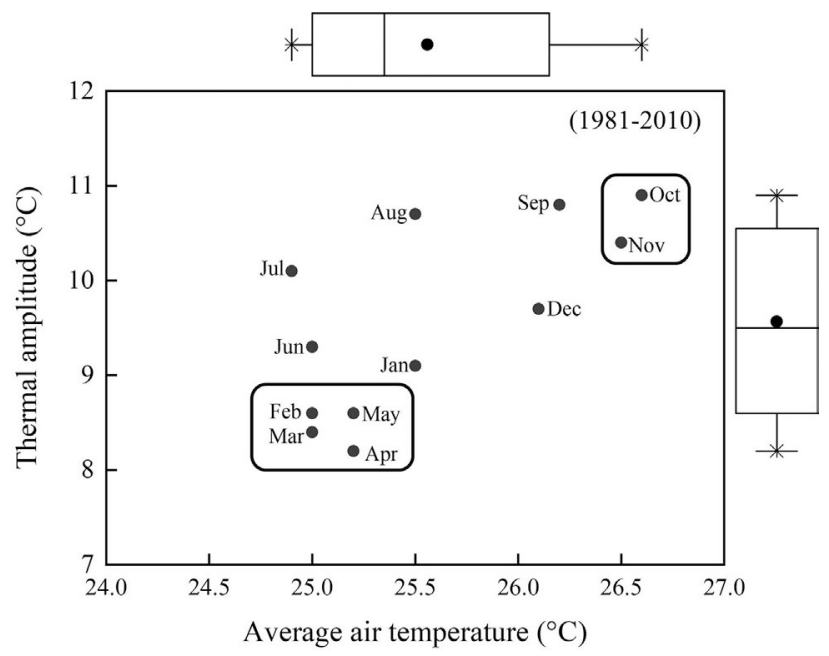

Figure 4 - Thermal amplitude of air temperature and average air temperature from January to December during the period 1981 to 2010 in Belterra, Pará. 
Table 1 - Analysis of variance of air temperature $(\operatorname{Tmax}=$ Maximum temperature; Tmed $=$ Average temperature, Tmin $=$ Minimum temperature, AT $=$ Amplitude), considering semester and quarterly periods based on the values of the two Climatological Normals (1961 to 1990 and 1981 to 2010 ) in Belterra, Pará

\begin{tabular}{|c|c|c|c|c|}
\hline \multicolumn{5}{|c|}{ Semester analysis } \\
\hline Treatments & Tmax & Tmed & Tmin & AT \\
\hline $\mathrm{S}_{1} 1$ & $29.4^{\mathrm{b}}$ & $24.6^{\mathrm{b}}$ & $20.6^{\mathrm{a}}$ & $8.8^{\mathrm{b}}$ \\
\hline $\mathrm{S}_{1} 2$ & $31.2^{\mathrm{a}}$ & $25.2^{\mathrm{ab}}$ & $20.4^{\mathrm{a}}$ & $10.8^{\mathrm{a}}$ \\
\hline $\mathrm{S}_{2} 1$ & $29.9^{\mathrm{b}}$ & $25.2^{\mathrm{b}}$ & $21.2^{\mathrm{a}}$ & $8.7^{\mathrm{b}}$ \\
\hline $\mathrm{S}_{2} 2$ & $31.6^{\mathrm{a}}$ & $26.0^{\mathrm{a}}$ & $21.2^{\mathrm{a}}$ & $10.4^{\mathrm{a}}$ \\
\hline CV (\%) & $1.9 \%$ & $1.8 \%$ & $2.6 \%$ & $4.7 \%$ \\
\hline \multicolumn{5}{|c|}{ Quarterly analysis } \\
\hline Treatments & Tmax & Tmed & Tmin & AT \\
\hline $\mathrm{T}_{1} \mathrm{JFM}$ & $29.4^{\mathrm{c}}$ & $24.6^{\mathrm{bc}}$ & $20.8^{\mathrm{abc}}$ & $8.6^{\mathrm{c}}$ \\
\hline $\mathrm{T}_{1} \mathrm{AMJ}$ & $29.5^{\mathrm{c}}$ & $24.6^{\mathrm{c}}$ & $20.4^{\mathrm{bc}}$ & $9.0^{\mathrm{bc}}$ \\
\hline $\mathrm{T}_{1} \mathrm{JAS}$ & $30.8^{\mathrm{abc}}$ & $24.8^{\mathrm{bc}}$ & $19.8^{\mathrm{c}}$ & $11.0^{\mathrm{a}}$ \\
\hline $\mathrm{T}_{1} \mathrm{OND}$ & $31.5^{\mathrm{a}}$ & $25.6^{\mathrm{ab}}$ & $20.9^{\mathrm{ab}}$ & $10.6^{\mathrm{a}}$ \\
\hline $\mathrm{T}_{2} \mathrm{JFM}$ & $29.9^{\mathrm{bc}}$ & $25.2^{\mathrm{bc}}$ & $21.2^{\mathrm{ab}}$ & $8.7^{\mathrm{c}}$ \\
\hline $\mathrm{T}_{2} \mathrm{AMJ}$ & $29.9^{\mathrm{bc}}$ & $25.1^{\mathrm{bc}}$ & $21.2^{\mathrm{ab}}$ & $8.7^{\mathrm{c}}$ \\
\hline $\mathrm{T}_{2} \mathrm{JAS}$ & $31.3^{\mathrm{ab}}$ & $25.5^{\mathrm{abc}}$ & $20.7^{\mathrm{abc}}$ & $10.5^{\mathrm{a}}$ \\
\hline $\mathrm{T}_{2} \mathrm{OND}$ & $32.0^{\mathrm{a}}$ & $26.4^{\mathrm{a}}$ & $21.6^{\mathrm{a}}$ & $10.3^{\mathrm{ab}}$ \\
\hline CV (\%) & $1.8 \%$ & $1.4 \%$ & $1.8 \%$ & $4.9 \%$ \\
\hline
\end{tabular}

Averages followed by tde same letter are not different at a $5 \%$ probability level, where abc are letters tdat correspond to tde studied groups. $\mathrm{S}_{1} 1$, indicates tde first semester (January to June) of tde first climatological normal (1961-1990); S 2, tde second semester (July to December) of tde first climatological normal; $S_{2} 1$ indicates tde first semester of tde second climatological normal (1981-2010) and $S_{2} 2$ tde second semester of tde second climatological normal. For tde first climatological normal, tde quarterly periods are $\mathrm{T}_{1} \mathrm{JFM}$, which corresponds to tde first quarter (January, February, March); $\mathrm{T}_{1} \mathrm{AMJ}$ is tde second quarter (April, May, June); $\mathrm{T}_{1} \mathrm{JAS}$ is tde tdird quarter (July, August, September); $\mathrm{T}_{1} \mathrm{OND}$ is tde fourtd quarter (October, November, December); For tde second climatological normal tde quarterly periods are $\mathrm{T}_{2} \mathrm{JFM}$ which corresponds to tde first quarter (January, February, March); $\mathrm{T}_{2} \mathrm{AMJ}$ is tde second quarter (April, May, June); $\mathrm{T}_{2} \mathrm{JAS}$ is tde tdird quarter (July, August, September); $\mathrm{T}_{2} \mathrm{OND}$ is tde fourtd quarter (October, November, December); AT - Tdermal Amplitude; CV (\%) Coefficient of Variation between tde semester and quarterly periods.

tures, with $2.6 \%$ for the minimums and $1.9 \%$ for the maximums.

There were no statistical differences in the maximum temperatures $\left(29.4{ }^{\circ} \mathrm{C}\right.$ and $29.9{ }^{\circ} \mathrm{C}$, respectively) in the first semester compared to the values of the two climatological normals. Nevertheless, the afternoons were warmer in the second semester when comparing the two climate series $\left(31.2{ }^{\circ} \mathrm{C}\right.$ and $31.6{ }^{\circ} \mathrm{C}$, respectively), indicating an increase in thermal conditions in recent years.

Minimum temperatures were similar with values of $20.6{ }^{\circ} \mathrm{C}$ and $20.4{ }^{\circ} \mathrm{C}$ (1961 to 1990 ) and $21.2{ }^{\circ} \mathrm{C}$ in the second normal, confirmed by the thermal amplitudes which were statistically similar, which were $8.8^{\circ} \mathrm{C}$ and $8.7^{\circ} \mathrm{C}$ inferior to the amplitudes from the second semester, which were $10.8^{\circ} \mathrm{C}$ and $10.4^{\circ} \mathrm{C}$. There was greater variability in the thermal amplitude during the semesters, as shown by the coefficient of variation of $4.7 \%$, when compared to the coefficients of the maximums, averages, and minimums, respectively.

Evaluation of the quarterly averages showed that between January and March (JFM) the means were $24.6{ }^{\circ} \mathrm{C}$ and $25.2{ }^{\circ} \mathrm{C}$, with similar thermal conditions during the two normals, but with different maximums $\left(29.4{ }^{\circ} \mathrm{C}\right.$ and $\left.29.9{ }^{\circ} \mathrm{C}\right)$ and minimums $\left(20.8{ }^{\circ} \mathrm{C}\right.$ and $21.2^{\circ} \mathrm{C}$ ), with similar thermal amplitudes.

For the quarter from April to June (AMJ) the averages and extremes were different, varying from $24.6{ }^{\circ} \mathrm{C}$ to $20.1{ }^{\circ} \mathrm{C}$ (averages); $29.5{ }^{\circ} \mathrm{C}$ and $29.9{ }^{\circ} \mathrm{C}$ (maximums); $20.4{ }^{\circ} \mathrm{C}$ and $21.2^{\circ} \mathrm{C}$ (minimums). Between July and September (JAS) the values were different for all three analyzed variables, with averages varying from $24.8{ }^{\circ} \mathrm{C}$ to $25.5^{\circ} \mathrm{C}$, maximums of $30.8{ }^{\circ} \mathrm{C}$ and $31.3{ }^{\circ} \mathrm{C}$, and minimums of $19.8^{\circ} \mathrm{C}$ and $20.7^{\circ} \mathrm{C}$.

The warmest quarter (October to December; OND) in Belterra (OND) had average temperatures of $25.6{ }^{\circ} \mathrm{C}$ and $26.4{ }^{\circ} \mathrm{C}$, with maximums of $31.5^{\circ} \mathrm{C}$ and $32.0{ }^{\circ} \mathrm{C}$, and minimums between $20.9^{\circ} \mathrm{C}$ and $21.6^{\circ} \mathrm{C}$. The largest thermal amplitudes occurred between July and September, varying between $11.0{ }^{\circ} \mathrm{C}$ and $10.5{ }^{\circ} \mathrm{C}$, similar to the amplitude from October to December in the first climatological normal $\left(10.6^{\circ} \mathrm{C}\right)$.

The maximum temperature during January to March in the first climatological normal was different than that of the second normal which had higher values that varied between $29.4{ }^{\circ} \mathrm{C}$ and $29.9{ }^{\circ} \mathrm{C}$, demonstrating higher maximums between 1961 and 1990 com- 
pared to 1981 to 2010 , with a coefficient of variation of $1.8 \%$.

Average air temperature during the first semester (January to March) did not vary in the two climatological normals. The differences observed were only in the last quarter (OND), which is the quarter with the highest temperatures, reaching values of $25.6{ }^{\circ} \mathrm{C}$ (1961 to 1990) and $26.4{ }^{\circ} \mathrm{C}$ (1981 to 2010$)$. The minimum temperatures in this quarter varied in the first normal, showing oscillations during the early morning before sunrise in Belterra, and was the hottest quarter.

In the second historical series the minimum temperatures were similar during the first two quarters, with higher values in the last quarter, reaching $21.6^{\circ} \mathrm{C}$.

Comparing the first two quarters (JFM and AMJ), the early mornings in Belterra did not show variation that could be detected by the equipment used at the meteorological station, but there was variation during the last two quarters. The thermal amplitudes reinforce that the variation during the first quarters of both normals were due to maximum temperatures. During the last two quarters of the year thermal conditions were inverted in the second climatological normal.

The ANOVA results show that air temperature in Belterra substantially increased during the 30 years between 1981 and 2010.

In the quarter April to June (AMJ) the average temperature during the first historical series was $24.6{ }^{\circ} \mathrm{C}$ and in the second it was $25.1{ }^{\circ} \mathrm{C}$, indicating an increase of $0.5^{\circ} \mathrm{C}$, which was statistically different by ANOVA. The highest average temperature increase occurred in the last quarter of the second climatological normal, with a value of $26.4{ }^{\circ} \mathrm{C}$ and a coefficient of variation of $1.4 \%$.

Figure 2.a shows that air temperatures continued to be higher during the second climatological normal (1981 to 2010) in the second semester (July to December). In the first climatological normal, average temperatures were between $24.3{ }^{\circ} \mathrm{C}$ and $25.8{ }^{\circ} \mathrm{C}$, the maximums varied from $29.2{ }^{\circ} \mathrm{C}$ to $31.9{ }^{\circ} \mathrm{C}$, and the minimums between $19.4{ }^{\circ} \mathrm{C}$ and $21.1^{\circ} \mathrm{C}$. In the second normal the averages varied between $24.9^{\circ} \mathrm{C}$ and $26.1{ }^{\circ} \mathrm{C}$, the maximums varied from $30.4{ }^{\circ} \mathrm{C}$ to $32.5{ }^{\circ} \mathrm{C}$, and the minimums between $20.3{ }^{\circ} \mathrm{C}$ and $21.7^{\circ} \mathrm{C}$.

At the semester timescale, minimum temperatures during the first and second semesters were similar in the two series, indicating that when analyzing average values in these two semesters the early mornings remain without variation, as shown by the statistical test at $5 \%$ probability.

In contrast, when comparing thermal amplitudes between these two semesters, there were differences, with greater amplitudes in the second with values of $10.8^{\circ} \mathrm{C}$ and $10.4{ }^{\circ} \mathrm{C}$, respectively (Table 1 ), showing a thermal effect due to incidence of solar radiation which caused higher maximum temperatures during this part of the year.
At the quarterly timescale, from January to March the values were similar in the two historical series, with average thermal amplitudes of $8.7^{\circ} \mathrm{C}$. The warmest quarters were July to September and October to December during the first climatological normal $\left(11.0^{\circ} \mathrm{C}\right.$ and $10.6{ }^{\circ} \mathrm{C}$, respectively). Nevertheless, only the quarter JAS maintained high temperatures similar to the two quarters from the series 1961 to 1990 , with a thermal amplitude of $10.5^{\circ} \mathrm{C}$, demonstrating that the warmest months in Belterra occur at the start of the second semester (July to September). According to $\mathrm{Hu}$ et al. (2014), there was a rapid increase in air temperature on a global scale after 1980, and beginning in 1990 temperatures continued increasing, and the period from 1980 to 2010 is considered to be the warmest 30 -year period on record as temperatures increased by $0.7^{\circ} \mathrm{C}$.

In Belterra, minimum temperatures were the highest recorded during the last period of 30 years (1981 to 2010) that have been analyzed, indicating possible anthropogenic effects, since in this quarter the soil is frequently being prepared for new annual crops (Villa et al. 2018b).

These effects can be explained by soil preparation processes, wherein there is an intense dispersion of soil particles to the surrounding atmosphere, which contributes to the formation of clouds and consequently impedes the conduction of heat to the atmosphere, possibly contributing to an increase in temperatures in the early morning in Belterra (Itterly et al., 2016; Betts and Dias, 2010), which occurs exactly during the period of soil preparation in each harvest year.

As the second climatological normal includes meteorological monitoring from the years 2006 to 2010 these data may be associated with the effects of expansion and consolidation of the grain production center in Pará. This consolidation occurred after the Soybean Moratorium, an agreement between the private sector and rural producers that soybeans would be purchased only from areas in the Brazilian Amazon that were planted without deforestation after July 2006 (Gollnow, Hissa, Lakes, 2018; Nepstad et al., 2014).

With respect to thermal conditions, considering soybean cultivars (Costa et al., 2018) with an average cycle of 107 days, on average the harvest occurs during the first semester of the year, and therefore the crop is subjected to thermal conditions that vary between $24.6{ }^{\circ} \mathrm{C}$ and $25.2^{\circ} \mathrm{C}$. This thermal range is considered optimum for soybeans according to Battisti et al. (2017), who reported a high productive capacity of soybeans between $20^{\circ} \mathrm{C}$ to $30^{\circ} \mathrm{C}$. Sentelhas et al. (2017), emphasized that air temperature also influenced the duration of the cycle of soybean cultivars by affecting the velocity of plant metabolic reactions, wherein temperatures less than $10^{\circ} \mathrm{C}$ or above $40^{\circ} \mathrm{C}$ limit crop development, because low temperatures limit growth and development of plants, and high temperatures pre- 
vents flowering, thus reducing the capacity for grain retention.

Kumagai and Sameshima (2014), used agrometeorological models to test if high temperatures would shorten the growth period and result in reductions in productivity for grain cultivars that are less sensitive to daylength. They showed that the magnitude of productivity reduction under conditions of high temperature is greater when cultivars are responsive to daylength, indicating that late cultivars have better productivity under conditions of higher temperature. Gibson and Mullen (1996) demonstrated that thermal variation between $30{ }^{\circ} \mathrm{C}$ to $35^{\circ} \mathrm{C}$ during the day and $20{ }^{\circ} \mathrm{C}$ to $30{ }^{\circ} \mathrm{C}$ at night promotes a reduction in the number and size of soybean seeds. Regions with low daily thermal variation and that maintain high temperatures are not indicated for soybean seed production.

The result presented in the current study, principally those in Fig. 4, reinforce that during the months from September to December values vary between $26.5{ }^{\circ} \mathrm{C}$ and $27.0^{\circ} \mathrm{C}$, demonstrating that in December thermal conditions are at the threshold that limits soybean development. It is common practice for soybean farmers to schedule their planting on the rains that begin in December. However, if the decision to plant is made using a calendar based on temperatures and not rainfall, then the recommended month for the start of soybean planting in Belterra is January, and productivity would then be a function of air temperature.

Santos et al. (2016) analyzed thermal conditions in areas cultivated with grains that surround the Flona Tapajos, and showed that soil temperatures were higher in 2009 compared to 2005 and 2015, principally in areas that border the northeast and southwest portions of the Flona Tapajós, which are areas of annual crops that had already been consolidated and well-established. These authors used satellite images and infrared thermography to show that higher temperatures occurred in areas with annual crops and in pastures undergoing degradation. In the northeast part of the FLONA the temperatures were highest because in this area the soil was exposed after harvest of the annual crops. Areas with native forest attenuate heat and are therefore providing an important ecosystem service (Costanza et al., 2014, Constanza et al., 2017), such as, for example, the thermal regulation provided by the Flona Tapajós Sustainable Conservation Unit (SCU). Forests attenuate heat differently than areas with cultivation of annual crops due to the different strata, diversity of crown cover, greater permeability of air advection, and a diverse range of evapotranspiration fluxes (Gonçalves $e t$ al., 2013, Chuanhao et al., 2017).

Considering that air temperature is also used to evaluate the production potential of forests, as in the Climatic Index (ICMW), proposed by Weck (1970), and its subsequent modifications, the average temperature of the warmest month occurred in November $\left(25.8^{\circ} \mathrm{C}\right)(1961$ to
$1990)$ and in October $\left(26.6{ }^{\circ} \mathrm{C}\right)(1981$ to 2010$)$. However, these estimates should consider the temperatures during the period of growth of crops, which in the region of this study is predominantly from January to June. Therefore, the thermal values that should be used should be from the month of January, which is the warmest month during this period without soil water deficits (Martorano et al., 2017), and $24.8{ }^{\circ} \mathrm{C}$ is the value that should be used as a function of biomass production in the Flona Tapajós between 1961 and 1990 , and $25.5^{\circ} \mathrm{C}$ should be used to estimate ICMW between 1981 and 2010 .

\section{Conclusion}

In this study the following conclusions are made:

- The climatological thermal regime in Belterra showed that the afternoons during the second semester (July to December) are warmer compared to the first semester.

- There was a difference in the average temperature in Belterra in the second semester based on data from the second climatological normal, reinforcing that during the period between 1981 and 2010 average temperature values were higher.

- On a semester basis, the early morning periods before sunrise in Belterra were not different, and therefore the increases in average temperatures are explained by warmer afternoons in the second semester, as confirmed by the thermal amplitudes.

- The increase in maximum temperature detected in the second semester in Belterra is explained by the values from October and November, which are the warmest months of the year in terms of average and maximum temperatures.

- The early morning periods before sunrise during the quarter from October to December were cooler according to the data from the second climatological normal.

- The largest thermal variations occurred during the second semester, with July to September having the highest values for thermal amplitude.

- The thermal climate pattern in Belterra shows that the early morning periods before sunrise in October and November were warmer during the last 30 years, according to the minimum temperature values from the second climatological normal.

- On a semester scale there was no difference in minimum temperatures, but quarterly analysis showed that the last quarter of the year (October to December) had higher values in the early morning periods before sunrise during 1981 to 2010 when compared to the entire climatological normal from 1961 to 1990.

\section{Acknowledgments}

The authors thank the promject titled "Projeto Base de Dados Agrometeorológicos" funded by the Banco da 
Amazônia, which provided a scholarship through FADESP to the second author. The authors also thank the National Meteorological Institute (INMET) for the excellent services provided to society through meteorological monitoring, climate and weather forecasting, and the continuous work on revising and reporting climatological normals.

\section{References}

ALMEIDA, C.A.; COUTINHO, A.C.; ESQUERDO, J.C.D.M.; ADAMI, M.; VENTURIERI, A.; DINIZ, C.G.; DESSAY, N.; DURIEUX, L.; GOMES, A.R. High spatial resolution land use and land cover mapping of the Brazilian Legal Amazon in 2008 using landsat-5/TM and MODIS data. Acta Amaz., v. 46, n. 3, p. 291-302, 2016.

BACHA, C.J.C.; RODRIGUEZ, L.C.E. Profitability and social impacts of reduced impact logging in the Tapajós National Forest, Brazil - A case study. Ecological Economics, v. 63, n. 1, p. 70-77, 2017.

BATTISTI, R.; SENTELHAS, P.C.; BOOTE, K.J.; CÂMARA, G.M.S.; FARIAS, J.R.B.; BASSO, C.J. Assessment of soybean yield with altered water-related genetic improvement traits under climate change in Southern Brazil. Europ. J. Agronomy, v. 83, n. 1, p. 1-14, 2017.

BETTS, A.K.; DIAS, M.A.F.S. Progress in understanding landsurface atmosphere coupling from LBA research. J Adv. Model Earth Syst., v. 2, n. 1, p. 1-20, 2010.

CHUANHAO W.; HU, B.X.; HUANG, G.; ZHANG, H. Effects of climate and terrestrial storage on temporal variability of actual evapotranspiration. Journal of Hydrology, v. 549, p. 388-403, 2017.

COE, M.T.; COSTA, M.H.; SOARES-FILHO, B.S. The influence of historical and potential future deforestation on the stream flow of the Amazon River - land surface processes and atmospheric feedbacks. J. Hydrol., v. 369, p. 165-174, 2009.

COSTA, D.C.; MARTORANO, L.G.; MORAES, J.R.S.C; LISBOA, L.S.S.; STOLF, R. Dinâmica temporal da pegada hídrica por cultivar de soja em polo de grãos no oeste do Pará, Amazônia. Revista Ambiente e Água, v. 13, n. 1, p. 1-10, 2018 .

COSTANZA, R.; De GROOT, R.DE; SUTTON, P.; PLOEG, S.; ANDERSON, S.J.; KUBISZEWSKI, I.; FARBER, S.; TURNER, R.K. Changes in the global value of ecosystem services. Global Environmental Change, v. 26, n. 1, p. 152-158, 2014.

COSTANZA, R.; DE GROOT, R.; BRAAT, L.; KUBISZEWSKI, I.; FIORAMONTI, L.; SUTTON, P; FARBER, S.; GRASSO, M. Twenty years of ecosystem services: How far have we come and how far do we still need to go? Ecosystem Services, v. 28, n. 1, p. 1-16, 2017.

DRUMOND, A.; MARENGO, J.A.; AMBRIZZI, T.; NIETO, R.; MOREIRA, L.; GIMENO, L. The role of Amazon Basin moisture on the atmospheric branch of the hydrological cycle: a Lagrangian analysis. Hydrology and Earth System Sciences Discussion, v. 11, n. 1, p. 10231046, 2014.
FEARNSIDE, F.M. Land-tenure issues as factors in environmental destruction in Brazilian Amazonian: The Case of Southern Pará. World Development, v. 29, n. 8, p. 13611372, 2001

GIBBS, H.K.; RAUSCH, L.; MUNGER, J.; SCHELLY, I.; MORTON, D.C.; NOOJIPADY, P.; SOARES-FILHO, B.; BARRETO, P.; MICOL, L.; WALKER, NF. Brazil's Soy Moratorium. Supply-chain governance is needed to avoid deforestation. Science, v. 347, p. 377-378, 2015.

GIBSON, L.R.; MULLEN, R.E. Influence of day and night temperature on soybean seed yield. Crop Sci, v. 36, n. 1, p. 98104, 1996.

GOLLNOW, F.; HISSA, L.B.V.; LAKES, T. Property-level direct and indirect deforestation for soybean production in the Amazon region of Mato Grosso, Brazil. Land Use Policy, v. 78, p. 377-385, 2018.

GONÇALVES, L.G.G.; BORAK, J.S.; COSTA, M.H .; SALESKA, S.R .; BAKER, I.; RESTREPO-COUPE, N.; MUZA, M.N.; POULTER, B.; VERBEECK, H.; FISHER, J.B.; ARAIN, M.A.; ARKIN, P.; CESTARO, B.P.; CHRISTOFFERSEN, B.; GALBRAITH, D.; GUAN, X.; VAN DEN HURK, B.J.J.M.; ICHII, K.; IMBUZEIRO, H.M.A.; JAIN, A.K.; LEVINE, N.; LU, C.; MIGUEZ-MACHO, G.; ROBERTI, D.R.; SAHOO, A.; SAKAGUCHI, K.; SCHAEFER, K.; SHI, M.; SHUTTLEWORTH, W.J.; TIAN, H.; YANG, Z.-L.; ZENG, X. Overview of the large-scale biosphere-atmosphere experiment in Amazonia data model inter comparison project (LBA-DMIP). Agric. For. Meteorol., v. 182, p. 111-127, 2013.

HATFIELD, J.L.; BOOTE, K.J.; KIMNBALL, B.A.; ZISKA, L.H.; IZAURRALDE, R.C.; ORT, D.; THOM-SON, A.M.; WOLFE, D. Climate impacts on agriculture: implications for crop production. Agron. J., v. 103, p. 351-370, 2011.

HU, S.; MO, X.; LIN, Z. The contribution of climate change to the crop phenology and yield in haihe river basin. Geographical Research, v. 33, p. 3-12, 2014.

IBAMA. Instituto Brasileiro do Meio Ambiente e dos Recursos Naturais Renováveis (2011). Áreas de Preservação Permanente e Unidades de Conservação \& Áreas de Risco. O que uma coisa tem a ver com a outra? Relatório de Inspeção da área atingida pela tragédia das chuvas na Região INSTITUTO DE PESQUISA ECONÔMICA APLICADA (IPEA). Código florestal: Implicações do PL 1876/99 nas áreas de reserva legal. Comunicados do IPEA, n. 96. 2011.

INSTITUTO NACIONAL DE METEOROLOGIA (INMET). Normais Climatológicas do Brasil, 1961-1990, 2009, Brasilia, DF. Disponível em: http://www.inmet.gov.br/por tal/index.php? $\mathrm{r}=$ clima/normaisclimatologicas Acessado em: março de 2019.

IPCC (Intergovernmental Panel on Climate Change). Summary for policymakers. In: STOCKER, T.F.; QIN, D.; PLATTNER, G.K.; TIGNOR, M.; ALLEN, S.K.; BOSCHUNG, J.; NAUELS, A.; XIA, Y.; BEX, V.; MIDGLEY, P.M. (eds), Climate Change 2013: The Physical Science Basis. Contribution of Working Group I to the Fifth Assessment Report of the Intergovernmental Panel on Climate Change. Cambridge University Press: Cambridge and New York, 27 p., 2013. 
ITTERLY, K.F.; TAYLOR, P.C.; DODSON, J.B.; TAWFIK, A.B. On the sensitivity of the diurnal cycle in the Amazon to convective intensity. J Geophys Res Atmos, v. 121, p. 8186-8208, 2016.

JAHFER, S.; VINAYACHANDRAN, P.N.; NANJUNDIAH, R.S. The role of Amazon river runoff on the multidecadal variability of the Atlantic ITCZ. Environ. Res. Lett., v. 15, 054013, 2020.

LOUREIRO, R.S.; SARAIVA, J.M.; SARAIVA, I.; SENNA, R.C.; FREDÓ, A.S. Estudo dos eventos extremos de precipitação ocorridos em 2009 no estado do Pará. Revista Brasileira de Meteorologia, v. 29, n. 1, p. 83-94, 2014.

LU, L.; DENNING, A.S.; SILVA-DIAS, M.A.; SILVA-DIAS, P.; LONGO, M.; FREITAS, S.R.; SAATCHI, S. Mesoscale circulations and atmospheric $\mathrm{CO}_{2}$ variations in the Tapajós region, Pará, Brazil. Journal of Geophysical Research Atmospheres, v.110, D21102, 2005.

MARENGO, J.A; NOBRE, A.C. Clima da Região Amazônica. In: CAVALCANTI, I.F.A.; FERREIRA, N.J.; SILVA, M.G.A.J.; DIAS, M.A.F.S. (Org). Tempo e Clima no Brasil. São Paulo: Oficina de Textos, p. 197-212, 2009.

MARENGO, J.A.; CHOU, S.C.; KAY, G.; ALVES, L.M.; PESQUERO, J.F.; SOARES, W.R.; SANTOS, D.C.; LYRA, A.A.; SUEIRO, G.; BETTS, R.; CHAGAS, D.J.; GOMES, J.L.; BUSTAMANTE, J.F.; TAVARES, P. Development of regional future climate change scenarios in South America using the EtaCPTEC/HadCM3 climate change projections: climatology and regional analyses for the Amazon, São Francisco and the Paraná River basins. Climate Dynamics, v. 38, p. 1829-1848, 2012.

MARENGO, J.A.; ESPINOZA, J.C. Extreme seasonal droughts and floods in Amazonia: causes, trends and impacts. International Journal of Climatology, v. 36, p. 1033-1050, 2015.

MARTORANO, L.G.; VITORINO, M.I.; SILVA, B.P.P.C.; MORAES, J.R.S.C.; LISBOA, L.S.; SOTTA, E.D.; REICHARDT, K. Climate conditions in the eastern amazon: rainfall variability in Belem and indicative of soil water deficit. African. Journal Agricultural Research, v. 12 , p. 1801-1810, 2017.

MARTORANO, L.G.; PEREIRA, L.C.; CEZAR, E.G.M.; PEREIRA, I.C.B. Estudos Climáticos do Estado do Pará, Classificação Climática (Kõppen) e Deficiência Hídrica (Thornthwhite, Matter). Belém: SUDAM/EMBRAPA, p. 53, 1993.

MORAES, J.R.S.C.; ROLIM, G.S.; MARTORANO, L.G.; APARECIDO, L.E.O.; BISPO, R.C.; VALERIANO, T.T.B.; ESTEVES, J.T. Performance of the ECMWF in air temperature and precipitation estimates in the Brazilian Amazon. Theoretical and Applied Climatology, v. 141, p. 803-816, 2020.

MORICE, C.P.; KENNEDY, J.J.; RAYNER, N.A.; JONES, P.D. Quantifying uncertainties in global and regional temperature change using an ensemble of observational estimates: The HadCRUT4 data set. J. Geophys. Res., v. 117, D08101, 2012.

NEPSTAD, D.; MCGRATH, D.; STICKLER, C.; ALENCAR, A.; AZEVADO, A.; SWETTE, B.; BEZERRA, T.; DIGIANO, M.; SHIMADA, J.; SERIOA, M,R.; ARMIJO,
E.; CASTELlO, L.; BRANDO, P.; HANSEN, M.C.; MCGRATH-HORN, M.; CARVALHO, O.; AND HESS, L. Slowing Amazon deforestation through public policy and interventions in beef and soy supply chains. Science, v. 344, p. 1118-1123, 2014.

NOBRE, C.A.; SAMPAIO, G.; BORMA, L.S.; CASTILLARUBIO, J.C.; SILVA, J.S.; CARDOSO, M. Land-use and climate change risks in the Amazon and the need of a novel sustainable development paradigm. P. Natl. Acad. Sci. USA, v. 113, p. 10759-10768, 2016.

PAGIOLA, S.; VON GLEHN, H.C.; TAFFARELLO, D. (orgs.). Experiências de Pagamentos por Serviços Ambientais no Brasil. Sao Paulo: SMA/CBRN, 336 p., 2013.

PATTANAYAK, S.K.; ROSS, M.T.; DEPRO, B.M.; BAUCH, S.; TIMMINS, C.; JONES, K.; ALGER, K. Climate change and conservation in Brazil: CGE evaluation of health and wealth impacts. Economic Geographyand Color Maps, v. 9, n. 1, p. 1-44, 2009.

PIZER, W.; ADLER, M.; ALDY, J.; ANTHOFF, D.; CROPPER, M.; GILLINGHAM, K.; GREENSTONE, M.; MURRAY, B.; NEWELL, R.; RICHELS, R.; ROWELL, A.; WALDHOFF, S.; WIENER, J. Using and improving the social cost of carbon. Science, v. 346, p. 1189-1190, 2014.

POORTER, L.; ASNDER, M.T.; THOMPSON, J.; ARETS, E.J.M.M.; ALARCON, A.; ALVAREZ-SANCHEZ, H.; et al. Diversity enhances carbon storage in tropical forests. Global Ecology and Biogeography, v. 24, p. 1314-1328, 2015.

R Core Team. R: A Language and Environment for Statistical Computing. R Foundation for Statistical Computing. Vienna, Austria, 2019. Disponível em: https://www.R-pro ject.org/.

REBOITA, M.S.; GAN, M.A.; ROCHA, R.P.; AMBRIZZI, T. Regimes de precipitação na América do Sul: Uma revisão bibliográfica. Revista Brasileira de Meteorologia, v. 25, n. 3, p. 185-204, 2010.

SALAHODJAEV, R. Intelligence and deforestation: International data. Forest Policy Econ., v. 63, p. 20-27, 2016.

SALVIANO, M.F.; GROPPO, J.D.; PELLEGRINO, G.Q. Análise de Tendências em Dados de Precipitação e Temperatura no Brasil. Revista Brasileira de Meteorologia, v. 31, p. 64-73, 2016.

SAMPAIO, G.; NOBRE, C.; COSTA, M.H.; SATYAMURTY, P.; SOARES-FILHO, B.S.; CARDOSO, M. Regional climate change over eastern Amazonia caused by pasture and soybean cropland expansion. Geophysical Research Letters, v. 34, L17709, 2007.

SANTOS, L.S.; MARTORANO, L.G.; BATALHA, S.S.A.; PONTES, A.N.; SILVA, O.M.; WATRIN, O.S.; GUTIERREZ, C.B.B. Imagens orbitais e termografia infravermelho na avaliação da temperatura de superfície em diferentes usos e cobertura do solo na Floresta Nacional do Tapajós e seu entorno, PA. Revista Brasileira de Geografia Física, v. 9, p. 1234-1253, 2016.

SENTELHAS, P.C.; BATTISTI, R.; SAKO, H.; ZENI, R.; RODRIGUES, L.A. Clima e produtividade da soja: variabilidade climática como fator controlador da produtividade, 2017. Boletim de Pesquisa-Fundação MT, v. 1, p. 25-41, 2017. 
SUTTON, R.T.; MCCARTHY, G.D.; ROBSON, J.S.B.; ARCHIBALD, A.T.; GRAY, L.J. Atlantic Multidecadal Variability and the U.K. ACSIS Program. Am. Meteorol. Soc., v. 99, p. 415-25, 2018.

VILLA, P.M.; MARTINS, S.V.; NOLASCO, S.; RODRIGUES, A.C.; MARTORANO, L.G. Linking agroforestry to REDD + activities in the Amazon: implications for biodiversity and carbon conservation. In: Pedro Eisenlohr. (Org.). Forest Conservation: Methods, Management and Challenges. 1ed. New York: Nova Science Publishers, Inc, v. 1, p.115-140, 2018a.

VILLA, P.M.; MARTINS, S.V.; OLIVEIRA NETO, S.N.; RODRIGUES, A.C. Anthropogenic and biophysical predictors of deforestation in the Amazon: towards integrating REDD+ activities. Bosque, v. 38, p. 433-446, 2017.

VILLA, P.M.; MARTINS, S.V.; OLIVEIRA NETO, S.N.; RODRIGUES, A.C.; VIEIRA, N.; DELGADO, L.; CAN-
CIO, N.M.; ALI, A. Woody species diversity as an indicator of the forest recovery after shifting cultivation disturbance in the northern Amazon. Ecol. Indic, v. 95, p. 687-694, 2018b.

WECK, J. An improved CVP-index for the delimitation of the potential productivity zones of forest lands of India. Indian Forester, v. 96, p. 565-572, 1970.

\section{Internet Resources}

Nações unidas Brasil, https://nacoesunidas.org/pos2015/ agenda2030/.

License information: This is an open-access article distributed under the terms of the Creative Commons Attribution License (type CC-BY), which permits unrestricted use, distribution and reproduction in any medium, provided the original article is properly cited. 